\title{
Experimental Study on Influence of Flow Rate Ratio in a Dehumidifier with a Solar Desiccant Apparatus
}

\author{
Choi, Kwang-Hwan* Fatkhur Rokhman**
}

*Dept. of Regeneration and Air Conditioning Engineering, Pukyong National University(choikh@pknu.ac.kr) **Graduate School of Dept. of Regeneration and Air Conditioning Engineering

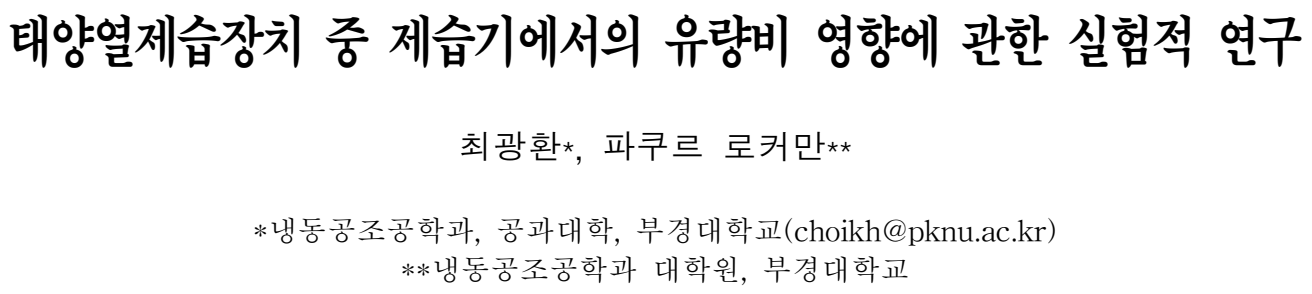

\begin{abstract}
제습기의 역할은 태양열제습냉방시스템 요소 중에서도 매우 중요하다. 본 논문은 이러한 특성에 맞추어 제작된 장 치를 갖고서 제습능력에 영향을 미치는 유량비를 바꾸어 실험한 결과이다. 실험은 크기가 $40 \mathrm{~m}^{3}$ 인 항온항습실을 대상 으로 이루어졌으며, 향류형 제습기의 수직 높이는 $0.4 \mathrm{~m}$ 로 고정되었다. 또한 충진층은 액체흡수제와의 접촉면을 넓게 하기 위하여 플라스틱 충진재로 채워져 있으며, 흡수제의 온도는 빠른 변화를 보기 위하여 $15^{\circ} \mathrm{C}$ 로, 농도는 $40 \%$ 로 고 정하였다.

액체흡수제의 유량과 습도가 높은 공기의 유량을 각각 3 단계로 바꾸어 실험한 결과, 풍량이 높을수록 제습기 효과 는 낮아졌으나, 전체적인 제습량에서는 많아졌다. 한편, 제습기에서 액체흡수제 유량이 많을수록 제습되는 수분량이 많아졌으나, 시간의 변화에 따라 제습되는 속도는 현저하게 낮아졌다. 따라서, 향후 실험에서는 유량의 변화 폭을 더 욱 확대해서 많은 실험 결과를 확보하고, 이를 모델링화 하여 높은 정확도를 예측할 필요가 있다.
\end{abstract}

Keywords : Dehumidifier(제습기), Effectiveness(효과), Lithium chloride(염화리튬), Flow rate(유량), Packing tower(제습탑)

\section{Nomenclature}

$\begin{array}{llll} & p & : \text { Saturation pressure, } \mathrm{Pa} \\ \omega & : \text { Humidity ratio }\left(\mathrm{kg} / \mathrm{kg}^{\prime}\right) & T & : \text { Absolute temperature, K } \\ \dot{m} & : \text { Mass flow rate }(\mathrm{kg} / \mathrm{s}) & \varepsilon & : \text { Dehumidifier's effectiveness }\end{array}$

투고일자 : 2011년 1월 19일, 심사일자 : 2011년 2월 25일, 게재확정일자 : 2011년 4월 25일

교신저자 : 최광환(choikh@pknu.ac.kr) 


\section{Subscript}

$\begin{array}{ll}\text { in } & \text { : inlet } \\ \text { out } & \text { : outlet } \\ \text { des } & \text { : desiccant } \\ \text { w } & \text { : water vapour } \\ \text { ws } & \text { : saturated water }\end{array}$

\section{Introduction}

To keep the chamber comfortable, people require a certain amount of ambient humidity, but humid air can cause mold and mildew to grow inside homes, which has various health risks.

When the air is cooled by below dew point, the humidity can be reduced. An air-vapor condensation method could be one of those in the cooling process. This system has merits such as high effectiveness of heat transfer, compact size and convenience for operation. But it is inefficient since it needs additional energy to overcool and reheat the air to achieve both temperature and humidity set-point.

In general, dehumidification process also can be achieved by a solid or liquid desiccant system. The unique beneficence they have is that the sensible and the latent heat can be processed separately. Desiccant systems are quite efficient in dealing with the latent load.

Liquid desiccant has several advantages over solid desiccant. The most outstanding feature is that the pressure drop through the liquid desiccant is lower than that of a solid desiccant system, it has low temperature for regeneration by solar energy and wasted heat. Liquid desiccant system combined with vapor compression system can reduce area of evaporation and condensation by $34 \%$, and power consumption by $25 \%$, compared with vapor compression system alone [1].

Zurigat al. [2] investigated the performance of an air dehumidifier using triethylene glycol (TEG) and evaluated in terms of the moisture removal rate and the dehumidifier effectiveness.

K. Daou et al [3] explained that the desiccant cooling is a simple technology which can be joined to other technologies to improve their efficiency.

S. Jane et al [4] had found that the proper selection of type of column with its operating parameters(ratio of solution to air flow rates, concentration of desiccant, packing size) resulted in high dehumidification.

Many researchers have developed analysis of the coupled heat and mass transfer dehumidifier processes in steady state.

This paper presents dehumidifier experiment results concerning on effectiveness and heat behavior in the packed bed of liquid desiccant system working under unsteady state condition.

\section{Experimental setup}

Dehumidification activity was executed by direct contact between desiccant and humid air in a packed tower of dehumidifier. Experimental apparatus of the dehumidifier this experiment consists of three main components, air blower, liquid pump, and a chiller. All components including piping are insulated to minimize heat loss. Fig. 1 shows the experimental schematic diagram and Table 1 illustrates configuration of an experimental apparatus. 


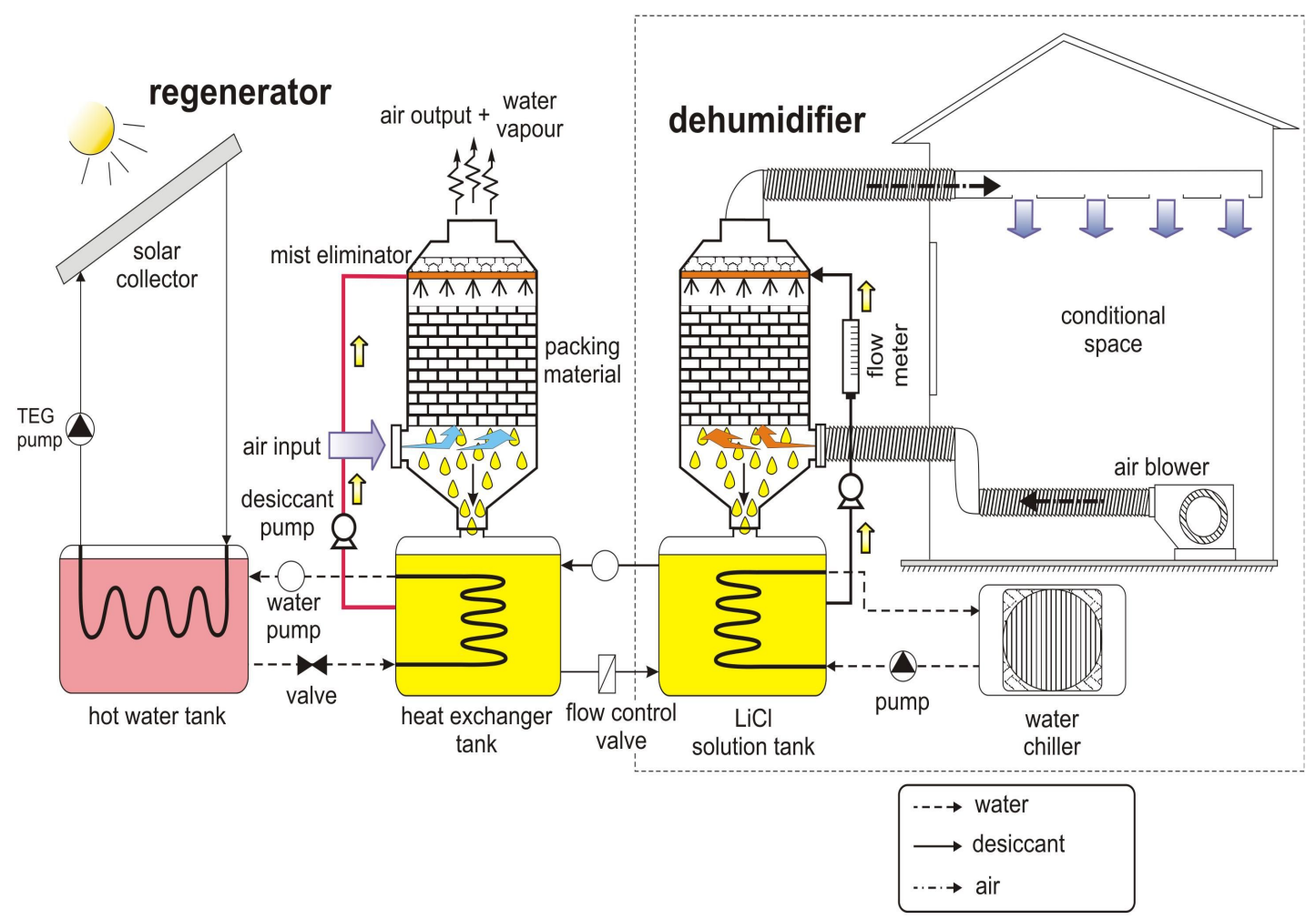

Figure 1. Schematic of the experimental system

The packed tower was filled with packing materials that is able to allow contacting area between desiccant and air be enlarged. A counter flow type of packing tower was structured to hold plastic packing materials and applied for this experiment as shown in Fig. 2.

Table 1. Experimental apparatus configuration

\begin{tabular}{l|l}
\hline Configuration & Value \\
\hline Volume of chamber & $40 \mathrm{~m}^{3}$ \\
\hline Dimension of packed & $\begin{array}{l}0.4 \mathrm{~m}(\mathrm{~L}) \times 0.4 \mathrm{~m}(\mathrm{H}) \times \\
0.4 \mathrm{~m}(\mathrm{~W})\end{array}$ \\
tower & $\begin{array}{l}0.7 \mathrm{~m}(\mathrm{~L}) \times 0.5 \mathrm{~m}(\mathrm{H}) \times \\
0.15 \mathrm{~m}(\mathrm{~W})\end{array}$ \\
\hline Size of desiccant tank & $\mathrm{R}=6 \mathrm{~cm}$ \\
\hline $\begin{array}{l}\text { Air input and output } \\
\text { cross section area }\end{array}$ & \\
\hline
\end{tabular}

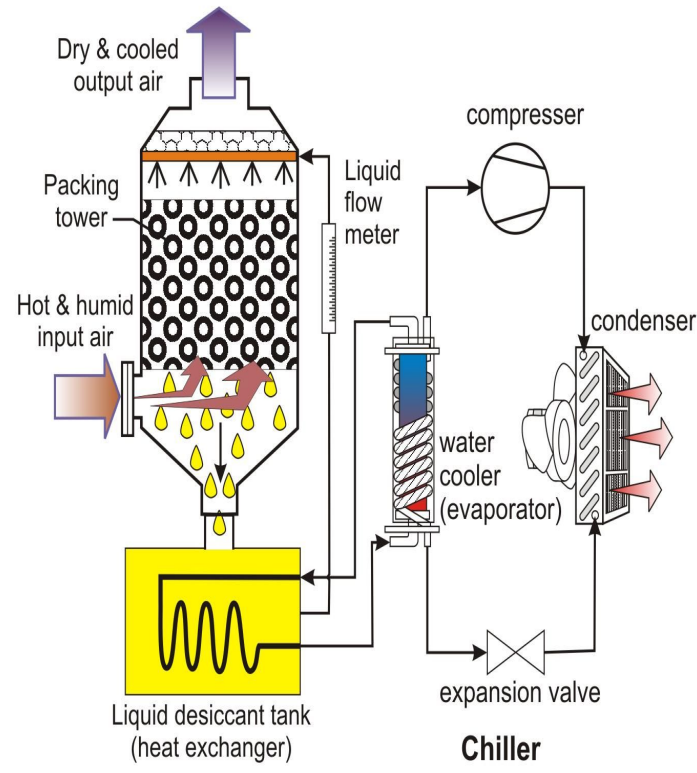

Figure 2. Flow direction in the dehumidifier

한국태양에너지학회 논문집 Vol. 31, No. 2, 2011 


\section{Experimental conditions and methods}

Actual experiments were conducted in a controlled chamber under the strict conditions for grasping thermal behavior this time. Table 2 revealed experiments conditions changed by different air volume against fixed flow rate of desiccant and vice versa in Table 3.

Table 2. Experimental conditions for variation of air velocity

\begin{tabular}{l|l}
\hline Configuration & Value \\
\hline Air velocity & $2,3,4 \mathrm{~m} / \mathrm{s}$ \\
\hline Desiccant flow rate & $8 \mathrm{~L} / \mathrm{min}$ \\
\hline Initial humidity ratio & $15 \mathrm{~g} / \mathrm{kg}^{6}$ \\
\hline
\end{tabular}

Table 3. Experimental conditions for variation of desiccant flow rate

\begin{tabular}{l|l}
\hline Configuration & Value \\
\hline Air velocity & $4 \mathrm{~m} / \mathrm{s}$ \\
\hline Desiccant flow rate & $4,6,8 \mathrm{~L} / \mathrm{min}$ \\
\hline Initial humidity ratio & $18.3 \mathrm{~g} / \mathrm{kg}^{6}$ \\
\hline
\end{tabular}

All experiments were also performed under constant circumstance inside controlled chamber and results were recorded by a data acquisition system after being reached the steady state. After initial condition for the experiment being reached, the liquid dehumidifier was turned on and operated for one hour of experiment.

\section{Calculation process}

The ASHRAE Standard was cited to calculate the humidity ratio accurately, which is necessary for estimation of the dehumidifier's effectiveness [3]. Also the saturation vapor pressure which is a function of temperature was calculated from Eq. (1).

$$
\ln p_{w s}=\frac{C_{1}}{T}+C_{2}+C_{3} T+C_{4} T^{2}+C_{5} T^{3}+C_{6} \ln T
$$

$$
\begin{array}{ll}
\text { here, } C_{1}=-5.8002206 & 10^{3} \quad C_{2}=1.3914993 \\
C_{3}=-4864023910^{-2} & C_{4}=4.176476810^{-5} \\
C_{5}=-1.445209310^{-8} & C_{6}=6.5459673
\end{array}
$$

After the saturation vapor pressure being striked the balance, the partial pressure of water vapor, which is a function of relative humidity and temperature, can be obtained from the relationship of Eq. (2).

$$
\phi=\left.\frac{p_{w}}{p_{w s}}\right|_{t, p}
$$

Furthermore the humidity ratio of the humid air is given by Eq. (3).

$$
\omega=0.62198 \frac{p_{w}}{p_{a t}-p_{w s}}
$$

In addition, the dehumidifier's effectiveness, $\epsilon$, is the ratio of the actual humidity ratio variance of the air passing through the dehumidifier to its variation under ideal condition, like as Eq. (4).

$$
\epsilon=\frac{\omega_{\text {input }}-\omega_{\text {output }}}{\omega_{\text {input }}-\omega_{\text {output } \min }}
$$

Therefore, the relationship between moisture removal rate and humidifier effectiveness can be assumed by the following equation. 


$$
m_{w}=\epsilon \dot{m}_{a}\left(\omega_{\text {input }}-\omega_{\text {output }}\right)
$$

The dehumidifying speed can be also estimated from the slope of humidity time, $\frac{d \omega}{d t}$, when the heating and cooling load was constant under the controlled chamber.

\section{Experimental results and reviews}

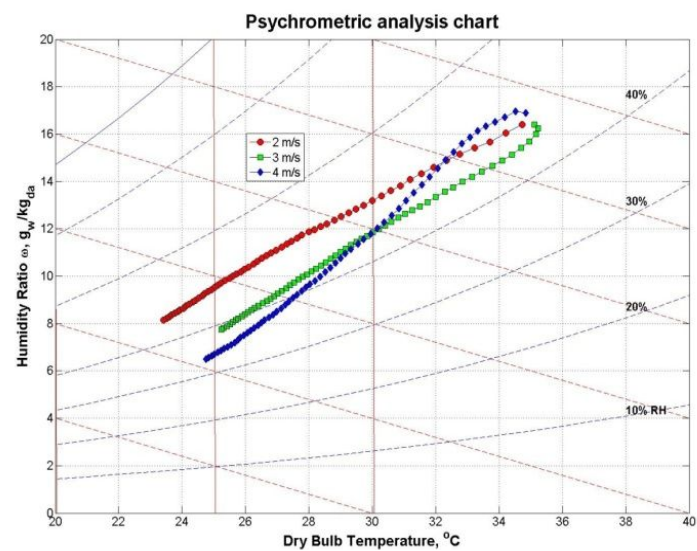

Figure 3. Humidity ratio changes with different air velocity steps

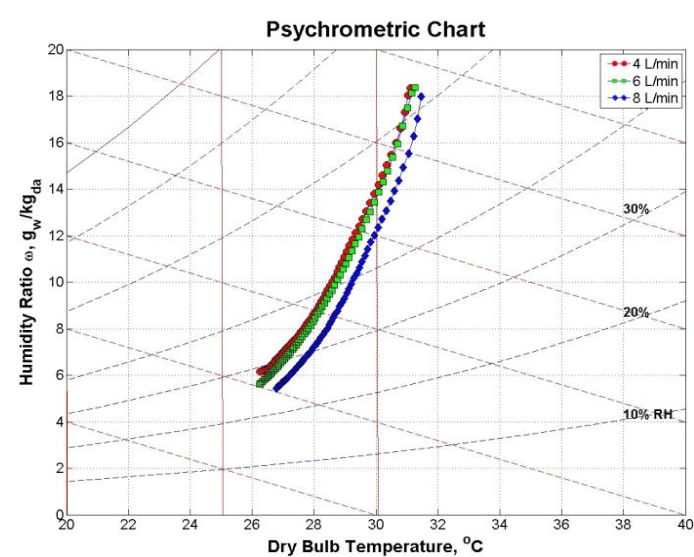

Figure 4. Humidity ratio changes with different desiccant flow rate steps
The psychometric diagrams, Fig. 3 and Fig. 4, have been shown that higher air velocity and greater desiccant flow rate had lower air humidity ratio at terminal, even though it consumed more electrical energy.

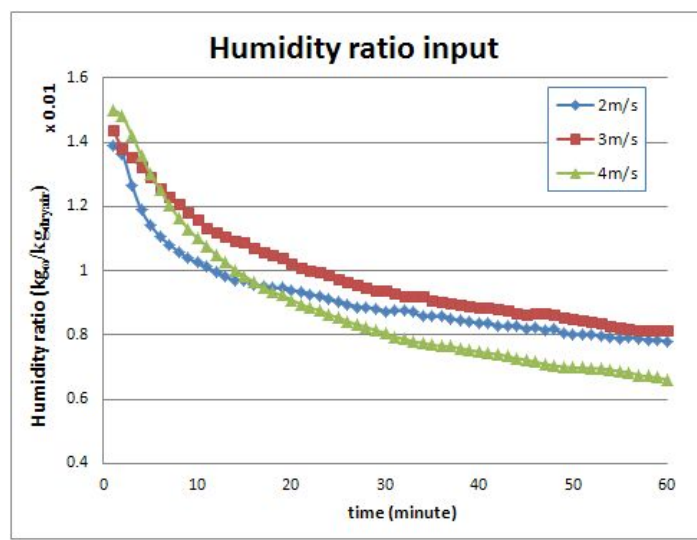

Figure 5. Humidity ratio changes with the different air velocity steps

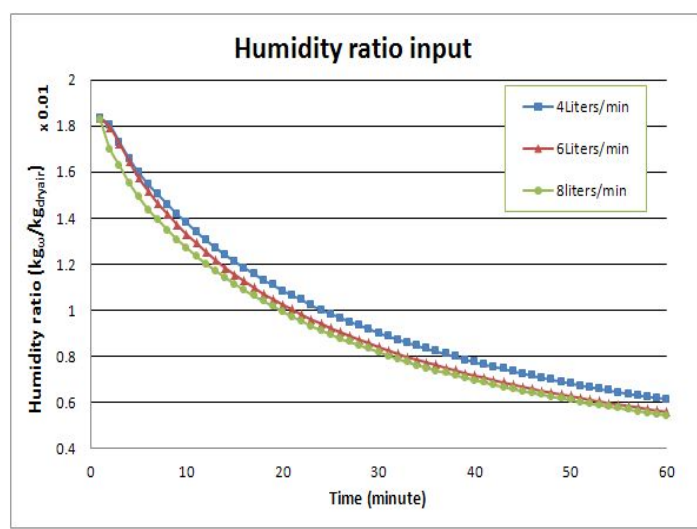

Figure 6. Humidity ratio changes with the different desiccant flow rate steps

Since the load chamber can be recognized as adiabatic, larger desiccant flow rate and higher air velocity can lead to the amount of air contacted with lithium chloride to be greater. 
In Fig. 5, the chart indicates decrease of humidity ratio input to air velocity variation. When the air velocity became faster, it had steep differences for humidity ratio and it eventually turned out become $0.6 \times 10^{-2} \mathrm{~kg} / \mathrm{kg}^{\prime}$ from $1.5 \times 10^{-2} \mathrm{~kg} / \mathrm{kg}^{\prime}$. This condition is also similar with experiment results in case of different flow rate as shown in Fig. 6.

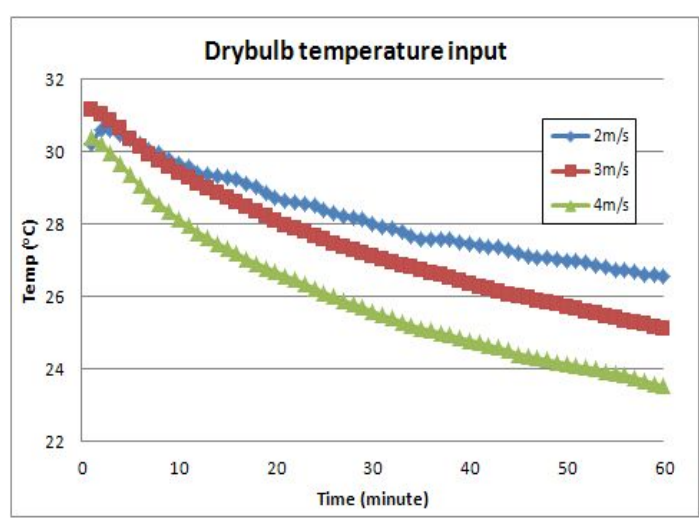

Figure 7. Dry bulb temperature changes with input air velocity steps

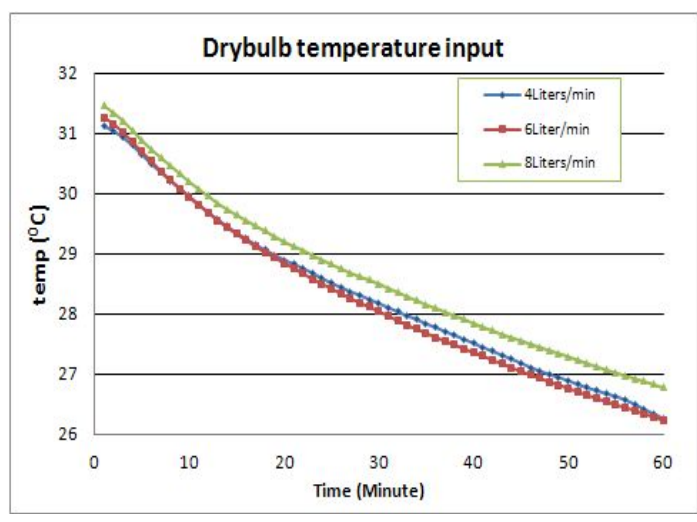

Figure 8. Dry bulb temperature changes with input desiccant flow rate steps

From Fig. 7, it was clear that the lower air velocity obtained the bigger temperature difference between inlet of the packed layer and outlet. However, from the side of affection of liquid desiccant, the larger liquid flow rate had more high temperature difference, even though its difference was the slightest thing between the case of $4 \ell$ $/ \mathrm{min}$. and $6 \ell / \mathrm{min}$. as shown in Fig. 8.

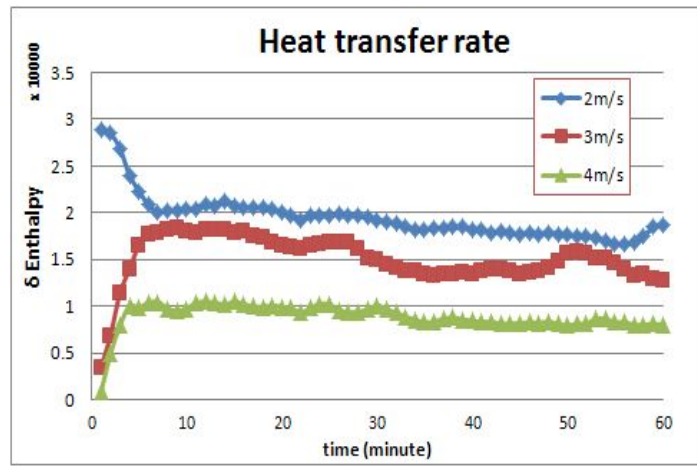

Figure 9. Enthalpy difference with different air velocity steps

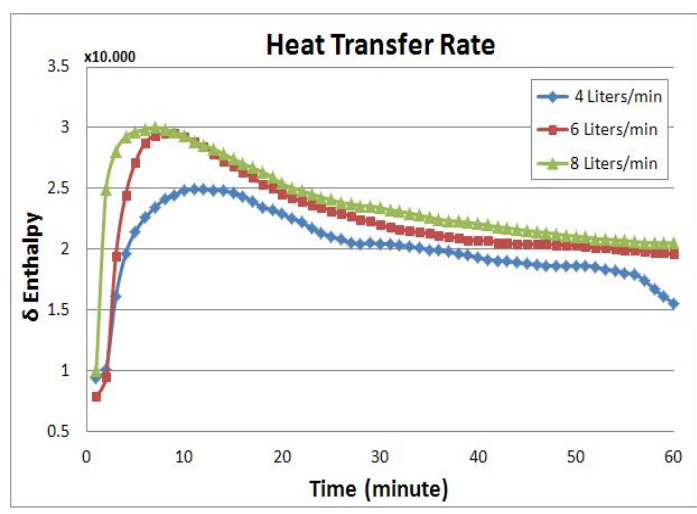

Figure 10. Enthalpy difference with different desiccant flow rate steps

When it comes to the enthalpy differences in the packed tower, the heat transfer rate also has same trend to be calculated. Fig. 9 and Fig. 10 have particularly shown those trends as having almost same slope that can indicate the dehumidifying capability. However, the slightest enthalpy differences in the both results turned out, but it resulted 
in accurate calculations by multiplying proper factors such as humidity ratio and air volume.

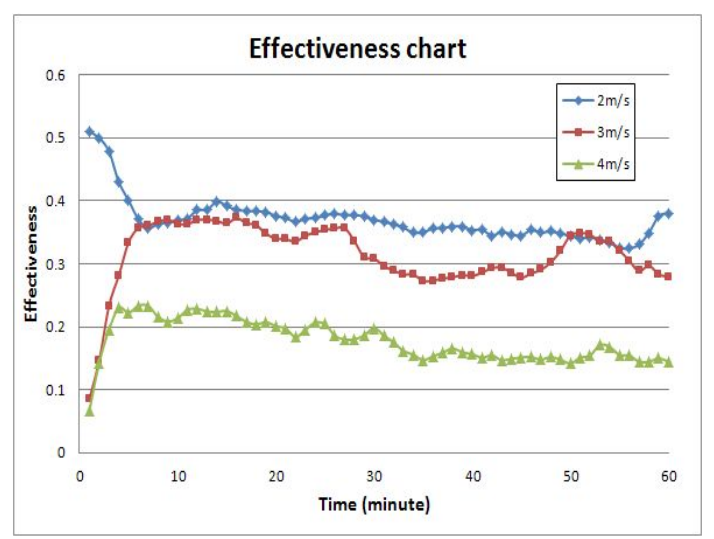

Figure 11. Effectiveness changes according to different air velocity

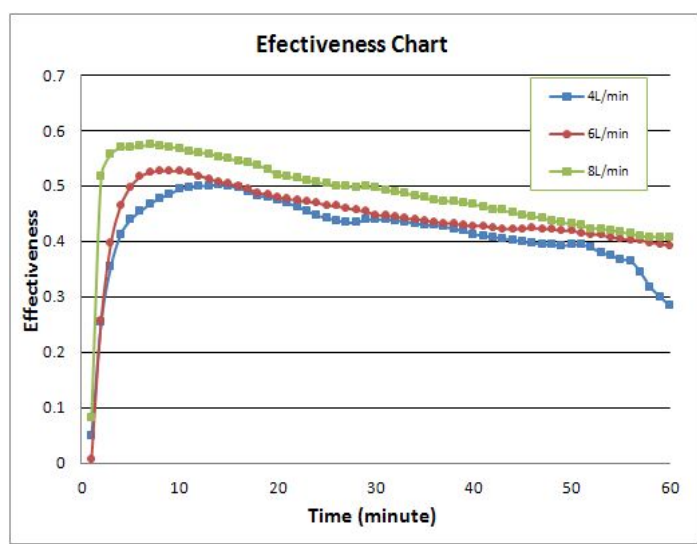

Figure 12. Effectiveness changes according to different desiccant flow rate

The dehumidifier's effectiveness defined already as shown in Eq. (4) was investigated for comparison of superiority of factor affection. Fig. 11 shows the low air velocity has high value in the dehumidifier's effectiveness and Fig. 12 also shows the high desiccant flow rate has more high effectiveness. This result gives useful information as a reference on blowing speed and desiccant flow rate controlling for energy saving of solar desiccant cooling system.

From these experiment results, it was very hard to conclude exclusive results which conditions can be better for dehumidifier's effectiveness. Thus, more concrete research will be required to confirm through kind of modelling which can grasp each factor's influence to the dehumidifier's effectiveness.

\section{Conclusions}

The experimental study regarding on a dehumidifier's characteristic in solar desiccant system has been verified based on the actual experiments data from different flow rate. In this paper, volumetric enthalpy differences and effectiveness of dehumidifier were calculated from different liquid-air contacting ratio in the packed layer of solar desiccant system, under being kept controlled as $2 \mathrm{~m} / \mathrm{s}, 3 \mathrm{~m} / \mathrm{s}, 4 \mathrm{~m} / \mathrm{s}$ of air velocity and $41 / \mathrm{min}$. 6l/min, $81 / \mathrm{min}$. of desiccant flow rate respectively.

Analysis was applied as the same fashion to figure out suitable flow rate ratio between liquid desiccant and air. The conclusions are as follows;

(1) The higher air velocity is, the faster dehumidification's speed is.

(2) The dehumidifier's effectiveness turned out low when the humid air velocity to the inlet became speedy.

(3) In addition, the higher desiccant flow rate is, the larger dehumidifier's effectiveness is at the beginning. However, it starts to be decreased slowly as the time goes.

(4) Thus more deep considerations on solar desiccant system should be pursued 
from the point of optimum modeling in the future.

\section{Acknowledgement}

This work was supported by the Pukyong National University Research Fund in 2010(PK-2010-076).

\section{References}

1. J. R. Howell, J. L. Peterson, Preliminary performance evaluation of a hybrid vapor compression/liquid desiccant air conditioning system, ASME Paper 86-WA/Sol. 9, 1986

2. Y. H. Zurigat, M. K. Abu-Arabi, S. A. Abdul-wahab, Air dehumidification by triethylene-glycol desiccant in a packed column, Energy Conversion and Management Vol.45, p.p $141-155.2004$

3. K. Daou, R. Z. Wang, Z. Z. Xia Desiccant cooling air conditioning: a review, Renewable and Sustainable Energy, 2004

4. S. Jain, P. K. Bansal, Performance analysis of liquid desiccant dehumidification systems, International Journal of Refrigeration, Vol. 30, pp. 861 - 872. 2007

5. ASHRAE Standard Handbook 2005(version), Chapter 6 (Psychrometric), ASHRAE publisher, 2005 